\title{
Dziennikarstwo obywatelskie, czyli jakie?
}

Streszczenie: Autorka rozważa w artykule różne aspekty obywatelskiej aktywności dziennikarskiej. Polemizuje z tezą, że dziennikarstwo obywatelskie ogranicza się jedynie do Internetu, oraz proponuje pewną kategoryzację w obrębie tego terminu. Dziennikarstwo obywatelskie zostato przez nią podzielone na cztery podstawowe typy: dziennikarstwo obywatelskie, którego podstawą działania są media obywatelskie tworzone przez rzeczywiste, a nie wirtualne społeczności; dziennikarstwo obywatelskie, które jest oparte na mediach obywatelskich (istniejących w sieci) tworzonych nie przez tradycyjną społeczność, a przez społeczność wirtualną; dziennikarstwo obywatelskie, którego podstawą działania są platformy tworzone przez media komercyjne, oraz dziennikarstwo obywatelskie, którego podstawą działania są platformy publiczne. W artykule podjęto również temat wykorzystywania spontanicznej aktywności obywateli przez podmioty komercyjne. Wskazano na potencjalne zagrożenia związane z tym zjawiskiem, w tym również na te, które mogą wpłynąć na ograniczenie różnorodności i niezależności prezentowanych treści. Zwrócono też uwagę na zasadność wspierania rozwoju niezależnych od dużych grup medialnych, oddolnych inicjatyw medialnych.

Słowa kluczowe: dziennikarstwo obywatelskie, media społecznościwe, niezależne media

\section{Wprowadzenie}

$D_{\text {dużą karierę. Można nawet powiedzieć, że stał się modny i nic nie wska- }}^{\text {ziennikarstwo obywatelskie to termin, który w ostatnim czasie zrobił }}$ zuje na to, żeby w najbliższym czasie jego popularność miała osłabnąć. Nie znaczy to jednak, że istnieje powszechna zgoda co do tego, co można, a czego nie można zakwalifikować do kategorii „dziennikarstwo obywatelskie". Dlatego pewne usystematyzowanie wiedzy na temat dziennikarstwa obywatelskiego wydaje się potrzebne. 
Poszukiwanie odpowiedzi na pytanie, czym jest dziennikarstwo obywatelskie, przeciętny polski internauta zacznie zapewne od odwiedzenia Wikipedii. Oto definicja, którą tam znajdzie:

Dziennikarstwo obywatelskie (ang. citizen journalism) - rodzaj dziennikarstwa uprawianego przez niezawodowych dziennikarzy w interesie społecznym. Jego powstanie i rozwój wiążą się z Internetem, bo to medium - w przeciwieństwie do prasy, radia czy telewizji - umożliwia każdemu interaktywne współtworzenie swojej zawartości i jej masowy kolportaż. Internet pozwala na tworzenie i publikację artykułów w czasie rzeczywistym oraz wspólną pracę w sposób wirtualny dziennikarzy z całego świata [Wikipedia].

W tej definicji w sposób bezpośredni powiązano początki istnienia dziennikarstwa obywatelskiego z Internetem. Na ścisły związek dziennikarstwa obywatelskiego z Internetem wskazuje też wielu innych autorów' Można jednak zadać pytanie, czy używanie terminu "dziennikarstwo obywatelskie" jedynie w kontekście inicjatyw internetowych jest słuszne? Czy dziennikarstwo obywatelskie nie istniało, zanim pojawiła się sieć? Wydaje się, że to właśnie „niezawodowi dziennikarze działający w interesie społecznym" tworzyli nielegalne gazetki i broszury w PRL i oni nadawali audycje Radia „Solidarność". Warto przy okazji podkreślić, że ten obywatelski odruch niezgody na to, co proponowały oficjalne media w owym czasie, był przecież wtedy zjawiskiem bynajmniej nie marginalnym. W PRL ukazywało się tysiące tajnych podziemnych periodyków w całym kraju. Szacuje się, że od czasu wprowadzenia stanu wojennego w grudniu 1981 roku w kraju pojawiło się 2077 tytułów podziemnych różnego typu. Były to wydawnictwa krajowe i regionalne o stosunkowo dużych nakładach dochodzących do 80 tys. egzemplarzy, ale również gazety zakładowe czy szkolne [Jakubowicz 2007: 165-166].

Coś takiego jak dziennikarstwo obywatelskie istniało chyba znacznie wcześniej, niż pojawiła się sieć internetowa. Zawężanie dziennikarstwa obywatelskiego jedynie do inicjatyw internetowych jest pewnego rodzaju uproszczeniem, choć rzeczywiście najczęściej tego typu działalność jest

1 Różne definicje „dziennikarstwa obywatelskiego" zostały przywołane w artykule Kariny Stasiuk-Krajewskiej Dziennikarstwo obywatelskie - o problemie granic dziennikarskiej profesji [Stasiuk-Krajewska 2010: 185-203]. 
kojarzona właśnie z siecią. Bez wątpienia też sam Internet okazał się akceleratorem takich inicjatyw.

Skoro więc dziennikarstwo obywatelskie nie ogranicza się jedynie do sieci, to warto sobie zadać pytanie, jakie główne nurty w tym dziennikarstwie możemy wyróżnić. Chciałabym przedstawić pewną kategoryzację dziennikarstwa obywatelskiego, licząc na to, że to zestawienie stanie się przedmiotem dyskusji i krytyki, w wyniku czego powstanie być może bardziej dojrzałe i kompletne opracowanie tego tematu.

Moim zdaniem dziennikarstwo obywatelskie można podzielić na cztery podstawowe typy:

1. Dziennikarstwo obywatelskie, którego podstawą działania są media obywatelskie tworzone przez rzeczywiste, a nie wirtualne społeczności;

2. Dziennikarstwo obywatelskie, które jest oparte na mediach obywatelskich (istniejących w sieci) tworzonych nie przez tradycyjną społeczność, a przez społeczność wirtualną;

3. Dziennikarstwo obywatelskie, którego podstawą działania są platformy tworzone przez media komercyjne;

4. Dziennikarstwo obywatelskie, którego podstawą działania są platformy publiczne.

Jak można zauważyć, czymś, co łączy kategorię pierwszą i drugą, jest istnienie medium obywatelskiego, w którego tworzenie są zaangażowani dziennikarze obywatelscy. Wypadałoby więc zdefiniować, co kryje się pod tym pojęciem. Podobnie jak w przypadku "dziennikarstwa obywatelskiego" nie jest to jednak tak proste, jak by się mogło wydawać. Co więcej, "obywatelskie" to niejedyny przymiotnik, jaki bywa stosowany w odniesieniu do mediów, które nie mieszczą się w znanych i oswojonych społecznie kategoriach, takich jak media „publiczne” i „komercyjne”. Można powiedzieć nawet więcej - bogactwo stosowanej terminologii w tej materii jest bardzo duże, co też w pewnej mierze utrudnia społeczne zrozumienie tego zjawiska. W stosunku do mediów wspomnianego typu używa się bowiem oprócz określenia „obywatelskie” takich wyrażeń, jak: „społeczne”, „,społecznościowe”, ,„środowiskowe”, , niezależne”, , ,niekomercyjne”, , uczest-

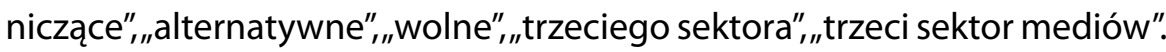
Nie chcę przez to powiedzieć, że każde z tych pojęć oznacza dokładnie to samo i można je stosować wymiennie. Implikują one przecież inne podejście do omawianego tematu przez zaakcentowanie takich, a nie innych cech szczególnych tego typu mediów. Na pewno jednak w znacznej mie- 
rze wszystkie wymienione media więcej łączy, niż dzieli. Ponieważ jednak "media obywatelskie" powiązane z I i II wymienionym przeze mnie typem dziennikarstwa obywatelskiego również nieco się między sobą różnią, postaram się zmierzyć z ich definicją przy okazji omawiania kolejnych typów dziennikarstwa obywatelskiego.

\section{Typy dziennikarstwa obywatelskiego}

\subsection{Typ I - Dziennikarstwo obywatelskie, którego podstawą działania są media obywatelskie tworzone przez rzeczywiste, a nie wirtualne społeczności}

W zaproponowanym podziale dziennikarstwa obywatelskiego w typie I znakiem szczególnym uczyniłam istnienie społeczności, która tworzy własne medium. To właśnie istnienie takiej społeczności odróżnia ten typ dziennikarstwa obywatelskiego od innych. Ważnym krokiem do zrozumienia, czym jest dziennikarstwo obywatelskie typu I, jest więc zrozumienie, czym jest sama społeczność. Zdaniem Ralpha E. Andersona, Irla Cartera, Gary'ego R. Lowe'a [2009: 76] za społeczność można uznać populację, której członkowie:

- świadomie identyfikują się ze sobą;

- mogą zamieszkiwać wspólne terytorium;

- angażują się we wspólne działania;

- mają jakieś formy organizacji, które umożliwiają społeczności dostosowanie się do otoczenia, w ten sposób odpowiadając na potrzeby jej członków.

Na to, że zbyt często aktywność obywateli w sieci utożsamiamy z tworzeniem takich społeczności, zwraca uwagę Rachel Happe, założycielka the Community Roundtable - wirtualnej platformy, na której można wymieniać się doświadczeniami w zakresie social media. Przedstawia ona również bardziej rozbudowany zestaw cech/warunków, jakie dana grupa powinna spełnić, by można ją było nazwać społecznością. Jej zdaniem społeczności można scharakteryzować w następujący sposób:

1. Są stałe, a nie czasowe (nie oznacza to, że ludzie nie opuszczają i nie dołączają do danej grupy, ale istnieją członkowie, którzy stanowią trzon danej społeczności i współdziałają przez długi okres); 
2. Społeczności tworzą się wokół koncepcji wspólnego celu, a nie wokół zbioru treści;

3. Społeczność podejmuje różnorodne konwersacje i działania przez różnych członków - nie ma jednego dyskursu - jest ich wiele;

4. Ludzie wewnątrz społeczności znają się i regularnie współdziałają bez scentralizowanych procedur i niekoniecznie w kontekście tego, co jest przedmiotem dyskusji całej społeczności;

5. Liderzy w społeczności pojawiają się w wyniku stałego przyjmowania aktywnej postawy w danej społeczności i są wybierani przez tę społeczność i zgodnie z jej interesami, a nie dlatego, że ktoś im polecił tę osobę wybrać [Happe 2008].

Jak ważne jest w tym typie dziennikarstwa obywatelskiego istnienie takiej społeczności, najlepiej oddaje wypowiedź Zane lbrahima z obywatelskiej stacji Bush Radio w Południowej Afryce. Podkreślił on, że „radio obywatelskie jest w $90 \%$ społecznością, a tylko w 10\% radiem" [Coyer 2007: 113].

Czymś, co odróżnia istnienie dziennikarstwa obywatelskiego I typu od innych form tego dziennikarstwa, oprócz społeczności, która za takim medium stoi, jest też istnienie medium przez tę społeczność tworzonego. W stosunku do radiowych i telewizyjnych inicjatyw obywatelskich, społecznych typu I najczęściej stosowanym określeniem w języku angielskim jest community media. W dokumentach i opracowaniach poświęconych temu typowi mediów najczęściej zwraca się uwagę na dwie podstawowe typy społeczności, które takie media tworzą: te, które łączy wspólne miejsce zamieszkania lub wspólnota interesów [Committee of Ministers of the Council of Europe 2009].

Czym zaś charakteryzują się same media obywatelskie przez takie społeczności tworzone? Jedna z najbardziej rozbudowanych definicji mediów obywatelskich została zaproponowana w Declaration of the Committee of Ministers on the role of community media in promoting social cohesion and intercultural dialogue [Committee of Ministers of the Council of Europe 2009]. W tej deklaracji podkreślono, że tego typu media powinny spełniać następujące warunki:

1. Być niezależne od rządowych, komercyjnych czy religijnych instytucji, jak również partii politycznych;

2. Działać na zasadach non profit;

3. Być oparte na współpracy wolontariuszy członków społeczeństwa obywatelskiego w prowadzeniu i zarządzaniu stacją; 
4. Działać na rzecz społeczeństwa obywatelskiego i społeczności, której służą;

5. Być własnością i być odpowiedzialne przed społecznością, której służą;

6. Być zaangażowane w aktywizację przedstawicieli różnych grup społecznych i międzykulturowy dialog.

Po tych definicyjnych wyjaśnieniach wypadałoby podać przykłady takich inicjatyw. Warto przy tej okazji zaznaczyć, że o ile media drukowane oraz internetowe w krajach demokratycznych mogą rozwijać się dość swobodnie, o tyle dostęp do eteru podlega już ścisłej regulacji. W przypadku tworzenia niekomercyjnych wydawnictw prasowych i inicjatyw internetowych, za którymi też przecież może stać rzeczywista, a nie jedynie wirtualna społeczność, największą barierą wejścia jest bariera finansowa. Podobne inicjatywy w eterze nie mogą się zaś rozwijać, jeśli nie istnieją odpowiednie uregulowania prawne, które im taki dostęp umożliwią. Wiele państw zdecydowało się na wprowadzenie przepisów, które ułatwiają obywatelom dostęp do eteru. Oprócz tradycyjnych dwóch sektorów radia i telewizji: publicznego i komercyjnego, w coraz większej liczbie państw istnieje też trzeci sektor - społeczny. W tej chwili ustawodawstwo uwzględniające i wspierające istnienie trzeciego sektora mediów obowiązuje na przykład w takich krajach europejskich, jak: Francja, Holandia, Dania, Austria, Irlandia, Szwecja, Finlandia, Niemcy, Wielka Brytania, Węgry. Rozwiniętym systemem mediów trzeciego sektora mogą się też pochwalić takie kraje, jak na przykład Stany Zjednoczone, Republika Południowej Afryki, Indie oraz Australia [Doliwa 2010: 67]. Również do polskiej ustawy o radiofonii i telewizji w 2001 roku wprowadzono zapis o nadawcy społecznym. Beneficjentami tego zapisu stały się jednak jedynie stacje o profilu religijnym [Doliwa 2010: 73].

Tego typu mediów jest tak wiele, że trudno wybrać jakieś reprezentatywne przykłady. Ale spróbujmy. Myślę, że do tego typu mediów na polskim rynku można na przykład zaliczyć Radio Żak z Łodzi, choć nie ma ono przyznanej koncesji na nadawanie społeczne, tylko akademickie. Jest to stacja studencka nadająca w eterze, za którą stoi rzeczywista społeczność studencka, która tworzy tę rozgłośnię. Stacja ma niekomercyjny charakter: nie nadaje reklam i nikt, włącznie z redaktorem naczelnym stacji, nie otrzymuje wynagrodzenia za swoją pracę. Co więcej, w tej rozgłośni obowiązują bardzo demokratyczne i niespotykane w innych rozgłośniach koncesjo- 
nowanych reguły zarządzania. Redaktora naczelnego rozgłośni wybiera walne zgromadzenie członków redakcji [Doliwa 2008: 162].

\subsection{Typ II - Dziennikarstwo obywatelskie, które jest oparte na mediach obywatelskich (istniejących w sieci) tworzonych nie przez tradycyjną społeczność, a przez społeczność wirtualną}

Tym, co odróżnia wyżej opisane dziennikarstwo obywatelskie od dziennikarstwa obywatelskiego typu II, jest charakter społeczności, która tworzy dane medium obywatelskie. Jest to specyficzna społeczność - wirtualna. Jedną z pierwszych osób, która starała się zdefiniować pojęcie społeczności wirtualnej, jest Howard Rheingold, który w 2004 roku określił ją jako: grupy ludzi, którzy mogą, lub nie, spotkać się twarzą w twarz i którzy wymieniają słowa oraz idee za pośrednictwem klawiatury [Doktorowicz 2004: 60]. Jest to więc nieco inna społeczność niż ta opisana w poprzednim podrozdziale.

Niewątpliwie to właśnie rozwój Internetu i powstanie społeczności wirtualnych przyczyniły się do rozwoju dziennikarstwa obywatelskiego na niespotykaną dotąd skalę. Nie brakuje entuzjastów tego zjawiska, którzy uważają, że rozwój dziennikarstwa obywatelskiego w sieci doprowadzi do całkowitej zmiany, jeżeli chodzi o dystrybucję informacji. Należy do nich z pewnością Dan Gillmor - autor książki We the media. Grassroots journalism by the people, for the people. We wstępie do niej podkreśla on, że „jesteśmy we wstępnej fazie czegoś wspaniałego - może nawet trochę przerażającego - czasu, w którym ludzie będą mogli odzyskać kontrolę nad informacjami" [Gillmor 2006: XVIII]. Zaangażowanie dziennikarskie obywateli, jak przekonuje wielu autorów, będzie zaś miało daleko bardziej istotne skutki niż urozmaicenie medialnego dyskursu. Ludzie bardziej zaangażowani w to, co się wokół nich dzieje, stają się po prostu lepszymi, bardziej świadomymi obywatelami [Gillmor 2006: XVIII; Jenkins 2007: 200].

Powstanie sieciowego dziennikarstwo obywatelskiego wyrosło z niezgody na komercjalizację rynku mediów i samego procesu przepływu informacji. Aktywność obywateli w sieci była więc początkowo globalnym sprzeciwem wobec globalizacji kapitału [Atton 2007: 63]. Pionierami rozwoju serwisów internetowych dziennikarstwa obywatelskiego, które w bardzo znaczący sposób przyczyniły się do rozwoju dziennikarstwa obywatelskiego typu II, są dwie inicjatywy, które przetarły szlaki dla następnych tego typu przedsięwzięć: Indymedia i OhmyNews. 
IMC - Idependent Media Center, czyli ośrodek niezależnych mediów, założyło kilkuset aktywistów podczas protestów przeciwko szczytowiWTO (Światowej Organizacji Handlu) w listopadzie 1999 roku w Seattle - notabene siedzibie niecieszącej się sympatią protestujących firmy Microsoft [Indymedia]. Domorośli dziennikarze nadawali wtedy relacje, dodawali na stronie internetowej własne teksty, materiały audio i wideo, jak również zdjęcia [Ritzer 2011: 142]. Celem twórców tego projektu było coś więcej niż tylko stworzenie jeszcze jednego lewicowego medium. Było nim raczej, zdaniem Johna Tarletona, reportera serwisu, stworzenie podwalin pod multimedialny obywatelski newsroom, który integrowałby aktywistów i umożliwiał rozpowszechnianie własnych wypowiedzi globalnemu odbiorcy bez konieczności przechodzenia przez jakikolwiek korporacyjny filtr [Bruns 2009: 100].

Jak podkreśla Matthew Arnison, jeden z twórców portalu Indymedia, dzięki Indymediom udało się zbudować prawdziwą wirtualną społeczność. Podczas gdy dotychczas poszczególne osoby wchodzące w jej skład mogły mieć poczucie, że nikt poza nimi nie myśli w ten sposób, mogły teraz przekonać się, że są inni myślący w podobny sposób ludzie, mimo że ten punkt widzenia nie jest reprezentowany w mediach tradycyjnych [Bruns 2009: 101].

Idee przyświecające działalności serwisu najlepiej oddaje hasło, które można znaleźć także na polskiej stronie tego serwisu: „Indymedia to sieć zwykłych ludzi, aktywistów i organizacji zajmujących się tworzeniem niezależnych mediów. Naszym wspólnym celem jest dostarczanie informacji o ważnych zjawiskach społecznych i politycznych w sposób całkowicie oddolny i niekomercyjny".

Warto jednak zaznaczyć, że zarówno ten, jak i wiele innych niezależnych serwisów dziennikarstwa obywatelskiego selekcjonuje nadsyłane teksty. W przypadku Indymediów selekcja informacji według deklaracji redakcji odbywa się na podstawie następujących kryteriów: są one komentarzami, a nie newsami, są powieleniem innej publikacji, są w sposób oczywisty nieprawdziwe lub zniesławiające, mają niewłaściwą zawartość (na przykład zawierają elementy "mowy nienawiści”) [Atton, Hamilton 2008: 100]. Wydaje się jednak, że twórcy serwisu znaleźli dobry sposób na zachowanie tak ważnej dla nich idei wolności słowa, przy jednoczesnym niedopuszczeniu do sytuacji, w której każdy mógłby napisać dowolnego rodzaju nieprawdę czy obelgę. Usunięte informacje są mianowicie publikowane w specjalnym serwisie „hidden stories” [Atton, Hamilton 2008: 100]. 
Trzeba jednak podkreślić, że choć część lokalnych portali Indymediów na stronie głównej umieszcza link odsyłający do listy tzw. hidden stories, to w niektórych przypadkach link ten nie jest wcale tak łatwo dostępny. Aby wejść na przykład na stronę z ukrytymi publikacjami w angielskim oddziale Indymedia, trzeba znać specjalny adres URL http://www.indymedia. org.uk/en/viewallposts.

Wchodząc na tę stronę 11 marca 2011 roku, można było przekonać się, że kontrola tekstów publikowanych przez użytkowników rzeczywiście działa. Na stronę z „hidden stores" trafił na przykład tekst zatytułowany We will not be silenced, w którym rzeczywiście nie brakowało słów obraźliwych i wartościujących. Oto fragment tekstu. Z uwagi na fakt, że część określeń użytych przez jego autora trudno przełożyć na język polski, przytoczę jego fragment w oryginale:

The dirty, corrupt establishment is trying to supress the truth of what happened back in 2005 and cover up their lies but they cannot silence us. We will NOT go away and we will do anything to make sure the truth is heard. Youtube is in the palm of the ConDem scum's hands and taking down our videos is proof that the autocratic ruling elite of this country will stop at nothing to protect their evil traditions and their weak and feeble members. BUT THE TRUTH IS OUT AND WE WILL NOT BE SILENCED.

Projekt Indymedia ma swoje lokalne strony w kilkudziesięciu państwach na sześciu kontynentach. Działa również polska wersja strony pod adresem http://poland.indymedia.org. Trzeba jednak podkreślić, że nie funkcjonuje ona zbyt prężnie. Na przykład 11 marca 2011 roku główną informacją promowaną przez serwis był news z 23 lutego 2011 roku o planowanym antyrządowym proteście w Grecji [Imc-pl 2011].

Sławę pionierskiego serwisu, który okazał się kamieniem milowym w rozwoju dziennikarstwa obywatelskiego, zyskał również portal OhmyNews. Został on stworzony przez Oh Yeon-Ho w 2000 roku w Korei Południowej. Hasłem przewodnim tej inicjatywy stało się zdanie „każdy obywatel może być reporterem" [Quinn, Lamble 2008: 51].

Zdaniem Chang Woo Younga [2009: 143], który opisał działanie portalu w książce Citizen journalism: global perspectives, należy on do najbardziej wpływowych mediów w Korei Południowej. Jak dowodzi autor, zainteresowanie serwisu kampanią Roh Moo Hyuna, która była pomijana 
przez media głównego nurtu, w sposób znaczący przyczyniło się do jego wyboru na prezydenta w 2002 roku.

Serwis przyjął nieco inną strategię selekcjonowania tekstów niż Indymedia. Z badań przeprowadzonych przez Chang Woo Younga [2009: 148] wynika, że tylko $70 \%$ tekstów nadsyłanych przez obywateli jest akceptowanych przez redakcję. Redakcja liczy 70 osób [OhmyNews, About] i zajmuje się nie tylko selekcjonowaniem tekstów, ale także ich pisaniem i poprawianiem: koryguje usterki stylistyczne i ortograficzne, czasami też zmienia tytuły artykułów. Te zaakceptowane przez redakcję trafiają na listę Ingul lub stronę główną, te, które nie zyskały akceptacji, są umieszczane na liście Saengnamu i nie zyskują statusu artykułu [OhmyNews, FAQ]. Na sukces koreańskiej i międzynarodowej wersji OhmyNews pracują 62 tys. zarejestrowanych współpracowników [OhmyNews, FAQ].

Do polskich portali wyrosłych z tego nurtu można zaliczyć na przykład Doorg.info. Serwis został uruchomiony w 2009 roku przez byłych użytkowników portalu Wiadomości24.pl [Matesky 2009]. Na stronach internetowych serwisu można znaleźć bezpośrednie nawiązanie do tradycji projektu Indymedia. Jego twórcy w sposób wyraźny dystansują się od serwisów tworzonych przez komercyjne koncerny medialne. Jak można się przekonać, czytając informacje o serwisie na stronie Doorg.info, niezależność od tych komercyjnych podmiotów jest pewną istotną wartością i lokomotywą ideową tego projektu.

Z biegiem lat coraz więcej wielkich korporacji medialnych (czyli podmiotów, w opozycji do których powstał ruch dziennikarstwa obywatelskiego) zaczęło wykorzystywać idee dziennikarstwa obywatelskiego do swoich celów, zwracając uwagę - z jednej strony - na możliwość publikowania ogromnej ilości darmowego kontentu, a z drugiej - starając się sprawiać wrażenie, że idee dziennikarstwa obywatelskiego są ideami korporacji medialnych - manipulując przy tym społecznością w taki sposób, aby zapomnieniu uległy przyczyny powstania tego zjawiska. My pamiętamy o tych przyczynach i dlatego stworzyliśmy niezależną od jakiegokolwiek koncernu medialnego platformę, która ma służyć publikowaniu materiałów przez dziennikarzy obywatelskich i informowaniu społeczeństwa o wydarzeniach pomijanych, marginalizowanych lub wypaczanych przez korporacyjne molochy medialne. Platformę, która ma służyć lepszemu przepływowi informacji i ma stanowić krok ku demokratyzacji mediów publicznych [Doorg.info]. 
Użytkownicy współpracujący z Doorg.info wyrażają zgodę jedynie na publikację danego materiału na stronie. Serwis nie może ich udostępniać osobom trzecim. Redakcja deklaruje, że stawia przede wszystkim na artykuły przemyślane i sprawdzone, a nie te o charakterze newsowym. I rzeczywiście na stronie nie są raczej publikowane informacje na temat bieżących wydarzeń. Wchodząc na stronę serwisu 14 marca 2011 roku, można było przekonać się, że wśród 18 artykułów promowanych na stronie nie tylko samym tytułem, ale też towarzyszącym mu lidem nie pojawiła się ani jedna informacja dotycząca trzęsienia ziemi w Japonii i jego następstw (choć był to wciąż temat numer $1 \mathrm{w}$ innych mediach). Publikowano za to recenzje książek, filmów, relacje podróżnicze. W dziale wydarzenia pojawiła się zaś informacja o planowanych zwolnieniach na Poczcie Polskiej, informacja o nieznanym dotąd filmie nakręconym tuż po katastrofie smoleńskiej i o gwałtach na lesbijkach w RPA.

Niektórzy autorzy zwracają uwagę, że czasami wirtualna społeczność, która stoi za takimi mediami, może się przerodzić w społeczność rzeczywistą. Chociażby społeczności tworzące enziny - elektroniczne odpowiedniki fanzinów - często rozwijają się do tego stopnia, że ich twórcy zaczynają kontaktować się również twarzą w twarz i wymieniać opinie nie tylko na tematy związane $z$ istnieniem danego enzina [Atton 2007: 63]. George Ritzer [2011: 142] w swojej najnowszej książce zwraca uwagę, że rola tego typu serwisów dziennikarstwa obywatelskiego, wraz z pojawieniem się blogów, które pełnią podobne funkcje, nieco zmalała.

\subsection{Typ III - Dziennikarstwo obywatelskie, którego podstawą działania są platformy tworzone przez media komercyjne}

Przyglądając się genezie powstania dziennikarstwa obywatelskiego, zarówno tego niedziałającego w oparciu o sieć internetową, jak i tego bezpośrednio związanego z rozwojem tego medium, należy jasno stwierdzić, że narodziło się ono w duchu i jako forma sprzeciwu wobec globalizacji, zwłaszcza globalizacji na rynku informacji. Wewnętrzną motywacją wielu dziennikarzy obywatelskich była niezgoda na sposób prezentacji, tematykę informacji przekazywanych przez media mainstreamowe i brak wpływu obywateli na kształt ich oferty medialnej. Dlatego połączenie: wielkie komercyjne koncerny medialne i dziennikarstwo obywatelskie jest dość zaskakujące. Dla tych, którzy pamiętają jeszcze, skąd wzięło się dziennikar- 
stwo obywatelskie i jakie idee za sobą niesie, jest to wciąż mieszanka trudna do zaakceptowania.

Zwraca na to uwagę chociażby jeden z twórców serwisu Doorg.info, Maciej Lewandowski [2009]. Pisze: „Uważam, że zbyt często jesteśmy tylko przedmiotem w rękach koncernów, niezbyt lubianym (ale niezbędnym) pracownikiem. Sądzę, że polska społeczność dziennikarzy oddolnych musi wypracować ścieżkę, która uniezależni nas - aktywnych dystrybutorów informacji - od zmonopolizowanych koncernów prasowych". Podobnie jak Maciej Lewandowski myśli wielu dziennikarzy obywatelskich. Bloger Memoryfive [2010] zauważa, że "serwisy dziennikarstwa obywatelskiego pod pozorem obiektywizmu i »wyrażania siebie« (cokolwiek to znaczy) korzystają w celach komercyjnych z materiałów nadsyłanych przez użytkowników".

O krok dalej idzie niemiecki badacz mediów Stephan Russ-Mohl [2010]. Jego zdaniem w przyszłości na rynku mediów przetrwają markowe produkty typu „Economist", których kupowanie jest trendy i wiąże się z potwierdzaniem statusu danej osoby. Przyszłość mediów mniej ambitnych będzie jednak miała jego zdaniem więcej wspólnego z biznesowym modelem „Tomka Sawyera", do którego to Michael Sprengelmeyer, wydawca Guadaloupe County Communicator, serwisu z Santa Rosa, porównuje dziennikarstwo obywatelskie działające $z$ wykorzystaniem platform tworzonych przez komercyjne grupy medialne. Aby dobrze zrozumieć, o co chodzi w tej strategii, trzeba przypomnieć sobie historię z malowaniem płotu. Zdaniem Sprengelmeyera w ten sam sposób, w jaki Tomek przekonał przyjaciół do opłacalności malowania płotu, można przekonać obywateli, żeby pisali artykuły i projektowali dla niego strony internetowe.

Jak przekonuje jednak Jarosław Tokarczyk [2011] - prezes „Edytora”, wydawcy dzienników, tygodników, miesięczników, gazet bezpłatnych, serwisów tematycznych i portali internetowych głównie na Warmii i Mazurach - współpraca dziennikarzy obywatelskich i koncernów medialnych może okazać się korzystna dla obu stron. Obecnie spółka rozwija projekt portali internetowych w 116 gminach województwa warmińsko-mazurskiego. Docelowo $80 \%$ treści tworzonych na tych stronach ma pochodzić od "dziennikarzy obywatelskich". Co ma koncern do zaproponowania dziennikarzom obywatelskim w zamian za ich pracę? Przede wszystkim szkolenia z zakresu dziennikarstwa i nowych technologii. Najlepsi mogą liczyć na ściślejszą współpracę z firmą i zacząć zarabiać. Niektóre teksty mają być drukowane w tradycyjnych tytułach wchodzących w skład „Edy- 
tora". Również materiały internetowe tworzone przez dziennikarzy obywatelskich mają być promowane w tych tytułach [Tokarczyk 2011].

Faktem jest, że coraz więcej serwisów dziennikarstwa obywatelskiego tworzonych przez komercyjne podmioty stara się w jakiś sposób motywować do pracy na rzecz serwisu w postaci: nagród za najlepsze teksty, nawiązywania z twórcami płatnej współpracy w należących do właściciela danej platformy dziennikarstwa obywatelskiego mediach tradycyjnych, umożliwiania autorowi zarabiania na reklamie zamieszczanej pod tekstem. Dla wielu wystarczającą motywacją pozostaje jednak na przykład awans artykułu na stronę główną czy duża liczba komentarzy, które są pod nim publikowane. To, co mogą zaoferować duże serwisy dziennikarstwa obywatelskiego (czyli głównie te działające w ramach dużych komercyjnych koncernów medialnych), to popularność, którą jest zdecydowanie trudniej zyskać, publikując na małych, oddolnie tworzonych platformach.

Sfera internetowego dziennikarstwa obywatelskiego, która wyrosła z oddolnych, niekomercyjnych inicjatyw, w coraz większym stopniu jest zagospodarowywana przez komercyjne grupy medialne, których głównym celem działania jest przynoszenie zysku. Dowodzą tego chociażby rankingi popularności serwisów dziennikarstwa obywatelskiego w Polsce. Prym wiodą w nich portale dziennikarstwa obywatelskiego tworzone właśnie przez duże grupy medialne. Co zyskują tego typu podmioty, inwestując w rozwój platform dziennikarstwa obywatelskiego? Możliwość promocji własnych produktów medialnych, wzbogacenie treści przez nie publikowanych, zwiększenie wpływów z reklam - to tylko niektóre z potencjalnych korzyści.

Czy można oburzać się na komercyjnych graczy na rynku medialnym, że inwestują w coś, co im się po prostu może opłacać? Oczywiście nie. To, o co można mieć żal do tego typu projektów, to to, że często ukrywają probiznesowy cel działania danych platform i mamią dziennikarzy obywatelskich z nimi współpracujących misyjnymi hasłami typu:

to projekt/miejsce dla wszystkich, którzy chcą "wyrazić się", czyli tych, którzy chcą pokazać światu, co myślą, jak myślą i o czym myślą [...]. Naszą misją jest stworzenie miejsca niezależnego. Niezależnego od linii politycznej redakcji, niezależnego od wszystkiego. Pragniemy krzewić idee wolnych mediów i wolności słowa [iThink]. 
Takie ukrywanie podstawowej motywacji działania wielu serwisów dziennikarstwa obywatelskiego przyczynia się do tego, że część publikujących i komentujących te publikacje osób nie ma świadomości, do jakiej grupy medialnej dana strona należy i, tym samym, kto na niej zarabia.

Niekwestionowaną pozycję lidera na rynku portali dziennikarstwa obywatelskiego zajmują Wiadomości24.pl z 40 tys. użytkowników [Wiadomości24.pl, O Wiadomościach 24.pl]. Jest to portal należący do Polskapresse - wydawcy dziennika "Polska” i wielu tytułów regionalnych i lokalnych. Serwis w sierpniu 2009 roku był odwiedzany średnio przez 660 tys. użytkowników, którzy generują ponad 2 mln odsłon [Gratka Technologie].

Zasady współpracy serwisu z użytkownikami określa regulamin [Wiadomości24.pl, Regulamin]. Można w nim znaleźć kilka zapisów, które wskazują na dominującą pozycję portalu w relacjach z jego użytkownikami. Przede wszystkim w części I punkcie 6 tego regulaminu operator zagwarantował sobie prawo usuwania materiałów, wpisów na forum, wypowiedzi, komentarzy, a także modyfikacji przesłanych materiałów (część I punkt 6 oraz część III punkt 18) oraz prawo zmiany regulaminu w dowolnym czasie (część I punkt 9). W części ll, dotyczącej użytkowników serwisu, możemy wyczytać, że każdy, kto rejestruje się w serwisie, wyraża jednocześnie zgodę na przetwarzanie swoich danych nie tylko w celach obsługi serwisu, ale także w celach marketingowych. Dokonując rejestracji, a tylko ta umożliwia publikowanie materiałów w głównej części serwisu, użytkownik ponadto zgadza się na rozpowszechnianie wizerunku i imienia oraz nazwiska nie tylko przez operatora, ale również tego, komu operator udzieli sublicencji na rozpowszechnianie naszych materiałów.

Również w części III omawianego regulaminu można dostrzec kilka niepokojących zapisów. Jeżeli rejestrujący się użytkownik dobrnie do tego etapu dość obszernego regulaminu, to dowie się, że przesyłając materiał do serwisu, jednocześnie zgadza się na nieodpłatne:

wytwarzanie i zwielokrotnianie dowolną techniką egzemplarzy utworu, w tym techniką drukarską, reprograficzną, zapisu magnetycznego oraz techniką cyfrową; wprowadzanie do obrotu, użyczenie lub najem egzemplarzy utworu; każde publiczne udostępnianie utworu, w tym jego udostępnianie: w taki sposób, aby każdy mógł mieć do niego dostęp w miejscu i czasie przez siebie wybranym, na jakichkolwiek nośnikach reklamowych w celu promocji Serwisu www.wiadomości24.pl, poprzez emisję lub reemisję $w$ radiu lub $w$ telewizji, poprzez publikację $w$ prasie, 
poprzez wyświetlanie lub publikację na jakichkolwiek nośnikach wewnętrznych lub zewnętrznych, w szczególności billboard lub citylight, za pomocą wszystkich technik i technologii telekomunikacyjnych obejmujących m.in. technologie GSM i UMTS, w szczególności poprzez SMS, IVR, WAP, MMS; wykorzystanie w innych utworach, w tym w utworach dramatycznych, muzyczno-dramatycznych, choreograficznych, audiowizualnych lub multimedialnych, a także wykorzystania w postaci stanowiącej aranżację, instrumentalizację lub przystosowanie utworu do potrzeb nowego wykonania.

Jeżeli dodamy do tego, że operator zagwarantował sobie „prawo do udzielania sublicencji według swego swobodnego uznania", to zauważymy, że pozycję operatora w stosunku do użytkownika serwisu trudno nazwać inaczej niż dominującą.

Nie można jednak również przemilczeć faktu, że serwis oferuje użytkownikom pewne korzyści. Najlepsze teksty tygodnia są nagradzane [Wiadomości24.pl, Wiadomości24.pl płaca za najlepsze newsy!]. Wprowadzono też możliwość sprzedaży powierzchni reklamowych w serwisie pod tekstami autorów za pośrednictwem firmy AdTaily. Zyski z tych reklam są przeznaczone dla tej firmy oraz autorów tekstów. Autorzy mogą też dostać połowę sumy, którą redakcja uzyska z tytułu udzielenia na materiał autora sublicencji innemu podmiotowi [Wiadomości24.pl, Regulamin].

Właściwie do kategorii dziennikarstwa obywatelskiego opartego na serwisach tworzonych przez komercyjne podmioty można też zaliczyć większość blogów, które są przecież tworzone przeważnie z wykorzystaniem popularnych serwisów blogowych. Należy jednak podkreślić, że blogi są postrzegane jako znacznie bardziej niezależna forma ekspresji niż publikacje w komercyjnych serwisach dziennikarstwa obywatelskiego. Niektórzy nawet uważają, że tworzenie blogów jest swego rodzaju remedium na „zawłaszczanie” dziennikarstwa obywatelskiego przez komercyjne podmioty. Bloger Memoryfive [2010] wręcz apeluje: „Użytkowniku! Jeśli chcesz zaistnieć w sieci - załóż bloga i zacznij go promować". Do tworzenia blogów zachęca też jeden z twórców serwisu Doorg.info, Maciej Lewandowski [2009]. Uważa on, że właśnie rozwój blogosfery jest obok „czekania na podmiot, który da nam narzędzie podobne do współczesnych portali zawiadywanych przez przedsiębiorstwa medialne, a który nie będzie oczekiwał w zamian żadnego zysku” i „radykalnej zmiany stosunków na linii: dziennikarz oddolny właściciel portalu, zmierzającej do powsta- 
nia sytuacji, w której to my będziemy podmiotem, określającym warunki gry" jednym ze sposobów przeciwdziałania komercjalizacji dziennikarstwa obywatelskiego.

\subsection{Typ IV - Dziennikarstwo obywatelskie, którego podstawą działania są platformy publiczne}

Ten typ dziennikarstwa może być np. realizowany w postaci wykorzystywania materiałów tworzonych przez dziennikarzy obywatelskich przez media publiczne. Znacznie bardziej obywatelski charakter mają jednak otwarte kanały - przestrzeń w eterze udostępniana nieodpłatnie obywatelom przez państwo. Idea otwartych kanałów rozwinęła się na przykład w Niemczech. Pierwszy z nich założono tam w 1984 roku. Teraz jest ich już około 80 [Bundesverband Offene Kanäle e.V.]. Otwarte kanały to przedsięwzięcia niekomercyjne, których celem jest umożliwienie otwartego dostępu do eteru obywatelom. Jedną z zasad obowiązujących w otwartych kanałach jest to, że to producent programu odpowiada pod względem edytorskim i prawnym za emitowany program [Buckley, Duer, Mende, O Siochru 2008: 188]. Zasada ta jest ściśle przestrzegana².

W Niemczech działalność otwartych kanałów jest regulowana na poziomie regionalnym, landowym. Na przykład zespół pracowników technicznych otwartego kanału w Berlinie zatrudnia bezpośrednio organ zajmujący się działalnością mediów na tym terenie - Medienanstalt Berlin-Brandenburg [Buckley, Duer, Mende, O Siochru 2008: 188].

\section{Podsumowanie}

W Polsce, podobnie jak w innych państwach demokratycznych, nie ma cenzury. Dostęp do publicznej agory nie jest jednak całkiem nieograniczony. To, że każdy z nas może bez przeszkód korzystać z wolności wypowiedzi, nie oznacza przecież jeszcze, że ze swoim komunikatem, upublicznionym

2 Jürgen Linke [2009], były wieloletni dyrektor otwartego kanału w Berlinie, wspomina, że zdarzały się sytuacje, że zgodnie $z$ tą zasadą na antenie tego kanału były nawet emitowane programy o zabarwieniu nazistowskim. W myśl wspomnianej zasady oraz zakazu cenzury prewencyjnej nikt nie może jednak zakazać obywatelowi emisji żadnego materiału. 
z pominięciem mediów głównego nurtu, jest w stanie dotrzeć do szerszego kręgu odbiorców. Rozwój dziennikarstwa obywatelskiego może tę sytuację jednak znacząco zmienić. Jak zauważa Chang Woo Young [2009: 150], do największych sukcesów OhmyNews należy zaliczyć zakwestionowanie hegemonii mediów tradycyjnych i stworzenie przestrzeni dla poglądów alternatywnych w stosunku do tych prezentowanych w mediach mainstreamowych. Z drugiej jednak strony, możemy zaobserwować coraz bardziej zauważalny trend wykorzystywania dziennikarstwa obywatelskiego i obłaskawiania dziennikarzy obywatelskich przez podmioty komercyjne. Moim zdaniem potencjalnie może to stanowić zagrożenie dla różnorodności i niezależności prezentowanych treści. Dlatego wciąż warto promować i wspierać rozwój niezależnych mediów obywatelskich (zarówno tych internetowych, jak i tradycyjnych).

Dziennikarstwo obywatelskie, jak starałam się wykazać w tym artykule, ma wiele form i odcieni. Zostały wyróżnione cztery podstawowe typy dziennikarstwa obywatelskiego: dziennikarstwo obywatelskie, którego podstawą działania są media obywatelskie tworzone przez rzeczywiste, a nie wirtualne społeczności; dziennikarstwo obywatelskie, które jest oparte na mediach obywatelskich (istniejących w sieci) tworzonych nie przez tradycyjną społeczność, a przez społeczność wirtualną; dziennikarstwo obywatelskie, którego podstawą działania są platformy tworzone przez media komercyjne i duże grupy medialne; dziennikarstwo obywatelskie, którego podstawą działania są platformy publiczne. Warto jednak podkreślić, że w ramach tych podstawowych gałęzi dziennikarstwa obywatelskiego istnieje wiele różnych podtypów i form, które czekają na skategoryzowanie i opisanie.

\section{Bibliografia}

Anderson Ralph E., Carter Irl, Lowe Gary R. 2009. Human Behavior in the Social Environment. United States: Aldine Transaction.

Atton Chris. 2007. A brief history. The Web and interactive media. [W:] K. Coyer, T. Dowmunt, A. Fountain (red.). The alternative media handbook. London-New York: Routledge.

Atton Chris, Hamilton James. 2008. Alternative journalism. Los Angeles-London-New Delhi-Singapore-Washington: Sage. 
Bruns Axel. 2009. Gatewatching. Collaborative online news production. New York: Peter Lang Publishing.

Buckley Steve, Duer Kreszentia M., Mende Toby, O Siochru Sean. 2008. Broadcasting, Voice, and Accountability: A Public Interest Approach to Policy, Law and Regulation. Washington: The University of Michigan Press.

Coyer Kate. 2007. Access to broadcasting: radio. [W:] K. Coyer, T. Dowmunt, A. Fountain (red.). The alternative media handbook. London-New York: Routledge.

Doktorowicz Krystyna. 2004. Społeczności wirtualne - cyberprzestrzeń w poszukiwaniu utraconych więzi. [W:] L. Haber (red.). Społeczeństwo informacyjne. Wizja czy rzeczywistość? Kraków: Akademia Górniczo-Hutnicza.

Doliwa Urszula. 2008. Radio studenckie w Polsce. Olsztyn: Wydawnictwo Uniwersytetu Warmińsko-Mazurskiego.

Doliwa Urszula. 2010. Elektroniczne media społeczne w Polsce. Stan obecny i perspektywy rozwoju. „Studia Medioznawcze” 4, s. 65-78.

Gillmor Dan. 2006. We the media. Grassroots journalism by the people, for the people. Beijing-Cambridge-Farnham-Köln-Paris-Taipei-Tokyo: O'Reilly.

Jakubowicz Karol. 2007. Zabawa w krzesła? Trzy sfery publiczne w Polsce. [W:] P. Dahlgren, C. Sparks (red.). Komunikowanie i obywatelskość. Wrocław: Astrum.

Jenkins Henry. 2007. Kultura konwergencji. Zderzenie starych i nowych mediów. Warszawa: Wydawnictwa Akademickie i Profesjonalne.

Quinn Stephen, Lamble Stephen. 2008. Online newsgathering: research and reporting for journalism. United States of America: Focal Press.

Ritzer George. 2011. Globalisation. The essentials. Oxford: Wiley \& Sons Ltd.

Stasiuk-Krajewska Karina. 2010. Dziennikarstwo obywatelskie - o problemach granic dziennikarskiej profesji. [W:] M. Sokołowski (red.). Nowe media. Nowe interpretacje. Olsztyn: WSP TWP, s. 187-203.

Young Chang Woo. 2009. OhmyNews. Citizen Journalism in South Korea Citizen journalism: global perspectives. [W:] S. Allan, E. Thorsen (red.). New York: Peter Lang Publishing.

\section{Źródła internetowe}

Bundesverband Offene Kanäle e.V. Open Channels in Germany. http://www.bok. de/doku/offene-kanaele-engl.pdf, 10.03.2010.

Committee of Ministers of the Council of Europe. 2009. Declaration of the Committee of Ministers on the role of community media in promoting social cohesion and intercultural dialogue. http://www.connexx-av.de/upload/m49a288b318ab0 _verweis1.pdf, 11.02.2011. 
Doorg.info. O serwisie. http://www.doorg.info/about, 11.02.2011.

Gratka Technologie. Wiadomości24. http://www.gratka-technologie.pl/nasze-realizacje/portale-informacyjne/43,aid,wiadomosci24pl.html, 12.03.2011.

Happe Rachel. 2008. Social Media is not Community. http://www.thesocialorganization.com/2008/07/social-media-is-not-communi-ty.html.

Imc-pl. 2011. http://poland.indymedia.org/, 11.03.2011.

Indymedia. About Indymedia. http://www.indymedia.org/en/static/about.shtml. iThink. O nas. http://www.ithink.pl/tekst/o-nas, 14.02.2011.

Lewandowski Maciej. 2009. Dziennikarstwo obywatelskie czy oddolne. http://www. eioba.pl/a/20sa/dziennikarstwo-obywatelskie-czy-oddolne, 14.03.2011.

Matesky. 2009. Wystartował nowy portal dziennikarstwa obywatelskiego. http://ireporter.blox.pl/html/1310721,262146,21.html?569591, 14.03.2011.

Memoryfive. 2010. Dziennikarstwo obywatelskie, czyli jak zarabiać na cudzej pracy. http://memoryfive.blogspot.com/2010/01/dziennikarstwo-obywatelskieczyli-jak.html, 12.01.2010.

OhmyNews. About. http://international.ohmynews.com/about/, 14.03.2011.

OhmyNews. FAQ. http://english.ohmynews.com/reporter_room/qa_board/qaboard_list.asp?page=1\&board=freeboard, 14.03.2011.

Russ-Mohl Stephan. 2010. Żegnaj, El Dorado! http://pl.ejo-online.eu/?p=915\#more-915, 12.02.2011.

Wiadomości24.pl.OWiadomościach24.pl-garśćpodstawowychinformacjidlaprasy. http://www.wiadomosci24.pl/artykul/informacje_dla_prasy_59474.html, 13.03.2011.

Wiadomości24.pl. 2010. Regulamin. http://www.wiadomosci24.pl/regulamin, 11.03.2011.

Wiadomości24.pl. Wiadomości24.pl płaca za najlepsze newsy! http://www.wiadomosci24.pl/artykul/wiadomosci24_pl_placa_za_najlepsze_newsy_34021. html, 2.03.2011.

Wikipedia. Dziennikarstwo obywatelskie. http://pl.wikipedia.org/wiki/Dziennikarstwo_obywatelskie, 8.03.2011.

\section{Inne}

Linke Jürgen. 2009. Rozmowa przeprowadzona przez autorkę w Halle w Niemczech podczas konferencji zorganizowanej przez Community Media Forum Europe "Community Media and European Policy" w dniach 13-14 marca 2009 roku.

Tokarczyk Jarosław. 2011. Rozmowa przeprowadzona przez autorkę w Olsztynie w dniu 15 marca 2011 roku. 


\section{Citizen journalism - what exactly does it mean?}

Summary: The author analysis different aspects of citizen activity in the journalistic field. She argues with the idea that the 'citizen journalism' is only limited to the Internet and suggests a kind of categorization within this concept. She divides 'citizen journalism' into four main groups: citizen journalism based on community media run by real and not only virtual communities; citizen journalism based on civil media created on the Internet by virtual communities; citizen journalism which is based on platforms run by commercial media groups and citizen journalism based on public platforms. In this article the problems related to a very intensive use of citizen journalists' work by big media groups is also discussed, including the issues connected with freedom of speech and independence limitations. The author also highlights the need of supporting independent from powerful media concerns and bottom-up initiatives.

Keywords: citizen journalism, community media, independent media 